\section{Nevrobiologi og moral}

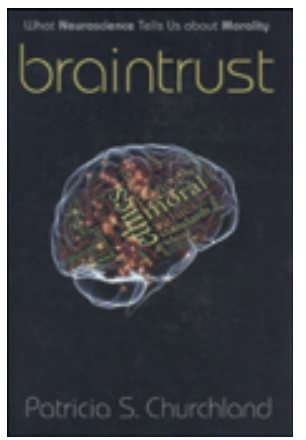

Patricia S. Churchland

\section{Braintrust}

What neuroscience tells us about morality. 273 s, ill. Oxford: Princeton University Press, 2011. Pris GBP 17

ISBN 978-0-691-13703-2

Hvilke implikasjoner har nevrobiologisk kunnskap for menneskesinnets status og våre begreper om moral og etikk? Dette er et av spørsmålene som er utgangspunktet for Braintrust. Forfatteren Patricia S. Churchland (f. 1943) er professor i filosofi ved University of California, San Diego. Hun og ektefellen, filosofen Paul Churchland (f. 1942), er blant de fremste innen fagfeltet nevrofilosofi, og de har begge søkt ny forståelse av bevisstheten og mentale fenomener i skjæringsfeltet mellom nevrovitenskap og bevissthetsfilosofi.

Argumentasjonen i Braintrust tar utgangspunkt i at mennesket er et resultat av evolusjonen og at vi har utviklet biologiske egenskaper som danner grunnlaget for moralsk handling. Det å ha omsorg for andre er forankret i en naturlig disposisjon til å ivareta eget avkom, og det å kunne forstå andre menneskers psykologiske tilstand er forankret i fordelen ved å kunne forutsi andre menneskers handlinger, hevder Churchland. Det å kunne løse problemer og å lære seg regler for sosialt samkvem har vært en fordel i evolusjonens løp. Hvordan har det seg at nevroner kan vise omsorg, spør Churchland retorisk i kapitlet Brain-based values, og peker på at hormonet oksytocin har en helt avgjørende betydning for menneskets moralske disposisjoner. Boken gir en imponerende oversikt over nyere nevrobiologisk og psykologisk forskning.

En leser med medisinsk bakgrunn vil kunne oppleve at forfatteren i kapittel etter kapittel sparker inn åpne dører, men mot slutten blir det mer tydelig hva som er forfatterens ærend: Hun ønsker å avlive ideen om at moralen kan ha et grunnlag i menneskets fornuft eller i en overnaturlig instans. Den filosofiske argumentasjonen for denne konklusjonen er imidlertid lettvint. Filosofiske innsikter fra Immanuel Kant (1724-1804) stedes til hvile over to korte boksider. Religiøse forestillinger bidrar som regel til å skape flere problemer enn de løser, mener forfatteren. Strategien er å peke på at de fleste etablerte etiske posisjoner lett blir absoluttistiske og at en etikk som er forankret i den menneskelige biologi, derfor er et bedre alternativ. Gjennom en reduksjonistisk manøver elimineres avleggs tankegods, mens innsikter fra Aristoteles (384-322 f.Kr.) og David Hume (1711-76) består syretesten. Innholdet i en ny nevroetikk skriver hun lite om, annet enn å poengtere at mennesket er biologisk konstruert for å lære å ha medfølelse og at det er viktig at samfunnet bygger institusjoner vi kan ha tillit til.

Braintrust viser hvordan menneskelige følelser og evne til sosialt liv er forankret i hjernens biologi, men viser i liten grad frem et alternativ til den etiske tenkningen som forfatteren med letthet kaster på idéhistoriens skraphaug.

\section{Jan C. Frich}

Avdeling for helseledelse og helseøkonomi

Institutt for helse og samfunn

Universitetet i Oslo

\section{Akuttmedisinsk harelabb}

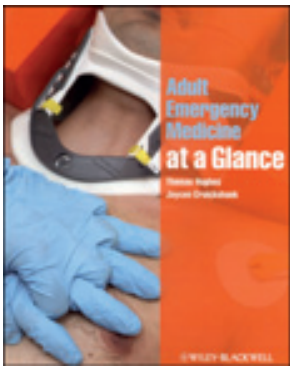

Thomas Hughes, Jaycen Cruickshank Adult emergency medicine at a glance 118 s, ill, tab. Chichester: Wiley-Blackwell, 2011. Pris GBP 22

ISBN 978-1-4051-8901-9

Markedet for oversiktslitteratur synes å være umettelig innen de fleste fag. Således er At a glance-serien fra dette forlaget i godt selskap, og med sine mer enn 30 ulike titler, markedsført hovedsakelig mot medisinstudenter. De av oss som tiltales av tynne bøker med flere illustrasjoner og tabeller enn «brødtekst», må ikke glemme at slike bøker bare er et tillegg til den grunnleggende og nødvendige - litteraturen. Det kan også være på sin plass å minne studentene om at det heller ikke finnes noen apper som kan befri oss fra ubehaget med å studere medisin, det være seg via lærebøker eller tidsskriftartikler.

Formatet er greit, med enkel, lettfattelig tekst, hvorav mye er satt med en font som skal likne på håndskrift for å illudere viktige notater. De tallrike og nesten naivistiske illustrasjonene er enkle og greie, og ofte i farger. Det er heller ikke alltid proporsjonalitet mellom størrelse på illustrasjon og medisinsk viktighet. Hovedstyrken er at boken er symptomorientert og på denne måten tar utgangspunkt i mange velkjente og utfordrende akuttmedisinske, eller snarere legevaktmedisinske, problemstillinger. Disse omtales kort over to sider, noe som begrenser mengden informasjon om hvert emne. Jeg fant ingen trykkfeil, og av faglige vurderinger var det bare noen få steder jeg er uenig med forfatterne. Boken avsluttes med 13 kasuistikker som leserne kan bryne seg på, helst før de leser de foreslåtte løsningene. Stikkordregisteret er omfattende og godt, og faktisk er partialtrykk av gasser angitt i kPa. Videre er akutt forvirring, funksjonstap, psykiatri og selvskading også viet oppmerksomhet. Denne viktige delen av akuttmedisinen blir ofte oversett.

Jeg savner referanser til noen sentrale og gode kilder, det være seg artikler, bøker, nettsteder eller annet. Videre er det noen pussigheter. Under for eksempel analgesi gir forfatterne ikke doseforslag ved lipid infusjon mot bupivakainforgiftning. Forfatterne forteller også om hvordan man benytter visuell analog skala (VAS) for å måle smerteintensitet, men sier intet om hvordan ønsket VASverdi kan nås og hva den bør være. Selv om mange temaer er berørt, fant jeg lite om generell anamnese og pasientundersøkelse, barnemishandling og fødsel. Derimot er det to glimrende kapitler om blodgassforstyrrelser og prediktiv verdi ved diagnostikk.

Det må være spennende å benytte studenter som konsulenter for faglitteratur, og flere fagforlag burde gjøre det samme. Gitt at man bruker denne boken som en litt artig og annerledes måte å få oversikt i faget på, synes jeg ikke at det er bortkastede penger å kjøpe den. Men som råd til en ung kollega som skal ha sin første kommunale legevakt, vil jeg heller anbefale Legevakthåndboken og forelesningsnotater.

\section{Guttorm Bratteb}

Akuttmedisinsk seksjon

Kirurgisk serviceklinikk

Haukeland universitetssykehus 